\title{
ニローラ式バドミントンマシンの高性能化
}

酒井 忍 ${ }^{* 1}$, 蜂谷 祥吾*2, 宮野 良平 ${ }^{* 3}$

\section{High performance of two roller-type badminton machine}

\author{
Shinobu SAKAI*1 ${ }^{*}$ Shogo HACHITANI ${ }^{* 2}$ and Ryohei MIYANO*3 \\ ${ }^{* 1}$ Department of Mechanical Engineering, Kanazawa University \\ Kakuma-machi, Kanazawa-shi, Ishikawa 920-1192, Japan \\ ${ }^{* 2}$ Imaging Products Division, PFU Limited \\ 98-2 Nu, Unoke, Kahoku-shi, Ishikawa 929-1192, Japan \\ ${ }^{* 3}$ Power System Management Department, Hokuriku Electric Power Company \\ 15-1 Ushijima-cho, Toyama-shi, Toyama 930-8686, Japan
}

\section{Received 29 August 2014}

\begin{abstract}
Badminton shuttlecock is constructed of 16 goose feathers from a waterfowl with a hemispherical cork. The shuttlecock is light in mass (approximately 5.2g), with a highly specific air resistance. For professional badminton players, the highest initial speed of the shuttlecock by a smash shot exceeds over $80 \mathrm{~m} / \mathrm{s}$, which is the fastest speed in all ball sports. Generally, it is extremely difficult to get the shuttlecock to speeds of over $30 \mathrm{~m} / \mathrm{s}$ with a launching machine without breaking the waterfowl feathers. In this study, a shuttlecock launching machine using two turn rollers for badminton exercises has been developed with a new launcher mechanism that includes an advanced holder device and a high rotational speed motor installed. In addition, a continuous launcher system which is able to discharge the 12 (maximum 96) shuttlecocks continuously at intervals of 1.5 seconds was designed. The results of the launching experiments using the two roller-type badminton machine show that the machine can launch the shuttlecock at mean initial speeds of up to $81.8 \mathrm{~m} / \mathrm{s}$, with a maximum flight distance of over $11 \mathrm{~m}$. The standard deviation of the shot and lateral directions are approximately $0.34 \mathrm{~m}$ and $0.12 \mathrm{~m}$, respectively. The launching performance of the badminton machine developed here has a performance far exceeding almost any commercial one, so the badminton machine can be used for harder practice by professional badminton players.
\end{abstract}

Key words : Sport engineering, Badminton, Launching machine, Feeding drive, Flexible structure, Flight behavior

\section{1. 緒言}

バドミントンは，国内はもちろん中国やマレーシア等のアジア諸国を中心に世界 160 ケ国, 2,000 万人以上の愛 好者がいる(Alam, et al., 2009). 最新のバドミントン用ラケットの質量は $90 \mathrm{~g}$ を切っており，小学生でも簡単にラ ケットを振ることができる. 硬式テニス用具と比較すると，シャトルコック（以下，シャトル）はテニスボール の約 $1 / 10$, ラケットは約 $1 / 3$ の質量しかない. また，バドミントンは，比較的容易に対戦相手とラリーを継続で きるため，手軽で身近なスポーツの一つとして老若男女問わず多くの人々に親しまれている.

一方，競技としてバドミントンをとらえると，オリンピックの正式種目に登録されており，世界のトップレベ ル選手のスマッシュ時の初速は $83 \mathrm{~m} / \mathrm{s} （ 300 \mathrm{~km} / \mathrm{h} ）$ を超え，これは球技スポーツ中の球の飛行速度としては最速 を誇る。またバドミントンは，スマッシュやハイクリア等の各種の打撃技術に加え，瞬発力や持久力等の運動能 力，さらには高い視覚能力も必要とされ，上達するのが難しいスポーツの一つである.

一般に試合球として用いられる水鳥シャトルは，半球形のコルク，ガチョウ等の天然の水鳥の羽根 16 枚, 羽根 を結束する紐糸および接着剤で構成され, その最大の特徵は, 大きな空気抵抗力による飛行速度の緩急差である.

\footnotetext{
No.14-00441 [DOI: 10.1299/transjsme.14-00441], J-STAGE Advance Publication date : 22 December, 2014

*1 正員, 金沢大学 理工研究域 機械工学系 (下920-1192 石川県金沢市角間町)

*2 正員，(株) PFU イメージプロダクト事業部（†929-1192 石川県かほく市宇野気又 98-2）

*3 北陸電力 (株) 電力流通部（广930-8686 富山県富山市牛島町 15-1）

E-mail of corresponding author: sakai@se.kanazawa-u.ac.jp
} 
スマッシュ時, 初速 $67 \mathrm{~m} / \mathrm{s}$ で打撃されたシャトルは, 相手コートの床に着地する僅か 0.6 秒後には $7 \mathrm{~m} / \mathrm{s}$ 前後の 速度にまで大きく減速する (Hubbard and Cooke, 1997), (蘆田他, 1998). 他の球技スポーツでは, これほど大きな速 度差は見られず，このスピード感こそがバドミントンの最大の魅力とも言える.

バドミントンの先行研究としては, シャトルの空力特性や飛行特性, 飛翔軌道等を解明する研究が多く行われ ている (Cooke, 1999, 2002), (綿貫, 鈴木, 2006), (Kitta, et al.,2011), (板倉,古村, 2013). また，スマッシュ等のストロ 一クにおける三次元動作分析やバイオメカニクス的な観点からの研究も多い (湯他, 1993), (Marshall and Elliott, 2000), (蘆田他, 1998). もちろんバドミントン競技における各種の打撃（ストローク）習得法を中心に，様々な練 習方法に関する研究も精力的に行われている (蘭, 2000), (Wonisch, et. al., 2003). しかし, これらの練習法はあくま で練習相手が存在することが前提であり，身近に優れたストローク技術や高い運動能力を有する監督や選手等が いない環境下では高度な練習は全くできない。このような恵まれた環境を持たない選手に対し，練習相手の代わ りとなる高性能なバドミントン用練習機（バドミントンマシン）が熱望されている.

現在まで試作，開発されたバドミントンマシンをシャトルの発射機構別に分類をすると，ラケット打撃式，圧 縮空気式，バネ・クランク式などがある (Tan, et. al., 2008), (石崎他, 2010), (Yousif and Yeh, 2011). しかしながら, これらの練習機の多くは, シャトルの初速は $30 \mathrm{~m} / \mathrm{s}$ 以下, 最大飛距離は $5 \sim 8 \mathrm{~m}$ 程度の性能しかなく, 実用的な 練習機とは言い難い. シャトルの高速発射を阻んでいる最大の要因は, シャトルの特殊性にある. シャトルは, 質量が約 $5.2 \mathrm{~g}$ と超軽量で, 半球状コルクと水鳥の羽根で構成された複雑な形状を有し, 人の手で強く握れば容易 に羽根が変形する程度の強度しかない．このような特徵を有するシャトルを初速 $30 \mathrm{~m} / \mathrm{s}$ 以上の高速で発射するこ とは非常に難しく, 仮に高速発射したとしても発射時に生じる衝撃力によって, 数回の発射でシャトルの羽根が 損傷または大きく破損することが多い.

このため著者らは，シャトルのコルク部を二つの対向するローラで挟持し，その摩擦力を利用してシャトルを 発射する二ローラ式バドミントンマシンの研究開発を行ってきた (酒井他, 2011a). 本マシンは, 最高初速度 $52 \mathrm{~m} / \mathrm{s}$, 最大飛距離 $11.5 \mathrm{~m} / \mathrm{s}$ であり, 小中学生を対象とした練習機としての発射性能は十分に有している. しかしながら, 高校生や大学生, さらには全日本のトップレベル選手を対象とする練習機としては, 性能不足は否めず, 特に初 速 $80 \mathrm{~m} / \mathrm{s}$ を超える高速発射性能が必要不可欠である. また，実際のバドミントン練習では，連続的にシャトルを 打撃（発射）しているにも関わらず，開発したマシンではシャトルを手動で挿入装置に 1 個ずつセットしなけれ ばならず，連続的に発射（連射）できない問題もあった。

そこで本研究では, 既に開発した二ローラ式バドミントンマシンの発射性能のさらなる高性能化を行った。一 つは連射性能の向上であり, 自動的にシャトルを供給し, 発射を繰返し行えるシャトル連射装置を開発する. も う一つは発射速度の高速化であり, 発射初速度 $80 \mathrm{~m} / \mathrm{s}$ を到達目標とした. 両者を達成した高性能マシンが完成す れば，全日本トップレベル選手用の実用的練習マシンとして，十分に耐え得るものと考えられる.

本論文では, 開発したシャトル連射装置の構造や供給機構について述べ，この連射装置を実際に二ローラ式バ ドミントンマシンに搭載させ, 連射実験の結果から得られた本マシンの発射速度や飛距離などについて詳述する. また，シャトル発射速度の高速化の検討およびその結果について記述する.

\section{2.ニローラ式バドミントンマシンとシャトル連射装置}

\section{$2 \cdot 1$ ニローラ式バドミントンマシン}

本研究では, YONEX製の水鳥シャトル（NEW OFFICIAL 3 番）を使用した．シャトルの外観および主要寸法 を図 1 に示寸．著者らが既に開発した二ローラ式バドミントンマシンの外観と代表寸法を図 2 に示す．シャトル を発射する回転ローラ $\left(N_{1}, N_{2}\right)$ は, 外径 $\phi 315 \mathrm{~mm}$, 厚さ $t=25 \mathrm{~mm}$ のものを二個用い, $H=1100 \mathrm{~mm}$ の高さに設 置されている. 両ローラはプーリー, Vベルト，シャフトを介して三相モータ（4 極， $0.2 \mathrm{~kW})$ とそれぞれ接続 されており, インバータ装置の周波数制御によってローラ回転数を 0 〜 $3150 \mathrm{~min}^{-1}$ の範囲で任意に調整できる.

本マシンのシャトル速度やショットの種類は, 両ローラ回転数を様々に変えることによって任意に変更できる. 両ローラの回転数を等しくすれば，スマッシュやドロップ等の縦方向に変化するショットとなる．一方，カット やドライブ等の横方向に軌道を変化させるには，左右で異なるローラ回転数でシャトルを発射すれば容易に再現 できる. また, 本マシンにはシャトルの発射仰俯角 $\Theta$ を可変できる調整機構を設けており, 調整ハンドルによっ 

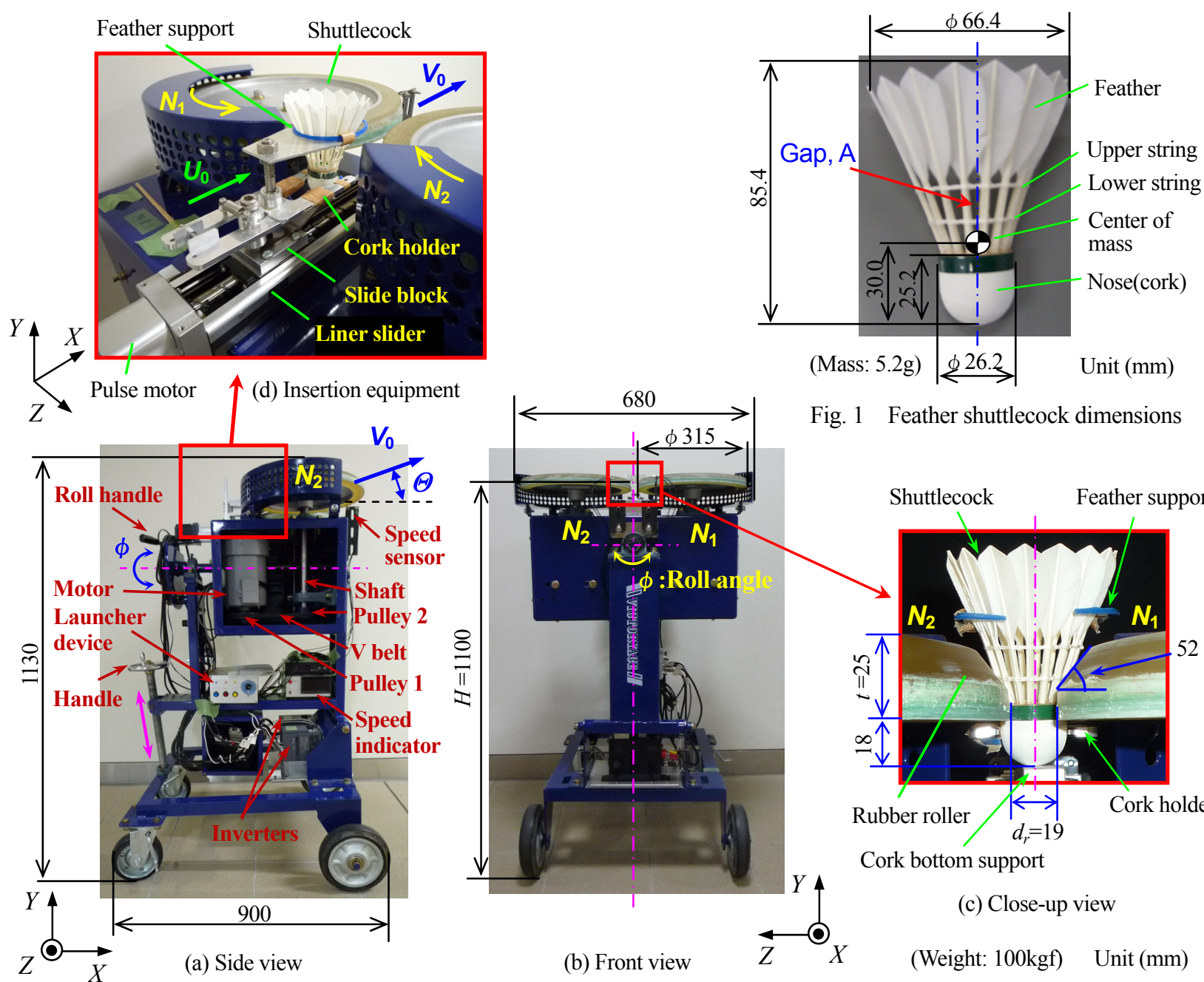

Fig. 2 The appearance and dimensions of the two roller-type badminton machine are shown. The shuttlecock held by the cork holder and feather support is discharged to be inserted in $X$-direction between the two polyurethane rubber rollers using a pulse motor and a liner slider. The badminton machine can launch the shuttlecocks at a wide range of speeds up to $52 \mathrm{~m} / \mathrm{s}$ and with various shot types such as smash, clear, drive, etc.

て を変更し，同じ種類のクリアやスマッシュでも仰俯角の異なるショットを発射できる．さらに，ロール回転 用ハンドルによって，両発射ローラを $X$ 軸周りにロール角 $\phi$ で傾斜可能な機構を付加した。 $\phi$ を可変することに より，ラケットを傾けて打撃したときの傾斜したシャトル姿勢で発射することができる．また，シャトルの発射 初速度は，発射ローラ前方に $25 \mathrm{~mm}$ 隔てて設置した二対の光電式センサを用いて計測している.

以上，開発した二ローラ式バドミントンマシンは，新しいシャトル発射機構によって，実際のバドミントン競 技で使用される多彩で高度なストロークを再現することができる実用的バドミントン練習機である，なお，本マ シンの詳細については, 参考文献 (酒井他, 2011a)を参照されたい.

\section{$2 \cdot 2$ シャトル連射装置}

前節で述べたバドミントンマシンは, 毎回シャトルを発射する度にシャトルを手動で挿入装置にセットする必 要がある．つまり，シャトルを自動的に連続発射することができないため，実際の練習機として使用することは 難しい，そこで，シャトルを自動的に 1 球ごとに供給し，発射することができるシャトル連射装置を設計，製作 した（図 3). 本連射装置では，市販されている1ダース（12 球）のシャトルケースをそのままケースホルダにセ ットできるようにした．ケースホルダは鉛直方向（Y 軸）を中心に回転できる構造となっており，最大 8 本のシ ヤトルケースを装填可能で，合計 12 球 $\times 8=96$ 球のシャトルをストックできる.

本連射装置は, ケース内の最上部にあるシャトルを押出棒先端のコルクで押し，ケースホルダ下端のシャトル ソケットから 1 球ずつバドミントンマシンの挿入装置に連続供給する．押出棒の押出量は，ステッピングモータ 
とリニアスライダで制御されており，一回の押出動作でシャトルが 1 球ずつ確実に供給されるように，ケース内 の残存シャトル数によって一回の押出量（約 $20 \mathrm{~mm} ）$ を調節している. また，押出動作でシャトルの羽根が損傷 せず，シャトルが 2 球同時に押出されることを防ぐため，ケースホルダ下端に樹脂製のテーパ付リング（シャト ルソケット）を設けた。 シャトルソケットの形状寸法は重要で試行錯誤によって決定した. その結果，テーパ部 はシャトル羽根のテーパ角度よりもやや大きく, リングの最小内径はシャトルの羽根外径よりも小さい $\phi 60.5 \mathrm{~mm}$, リング幅 $14 \mathrm{~mm}$ にした. このときシャトルは同時に 2 球出ることなく, 繰返し 1 球ずつ押出供給できた.

\section{$2 \cdot 3$ 連射装置を用いたシャトル連射実験および結果}

製作した連射装置をバドミントンマシンに設置し, 両者を連動させたシャトル連射実験を行った. 実験環境は,

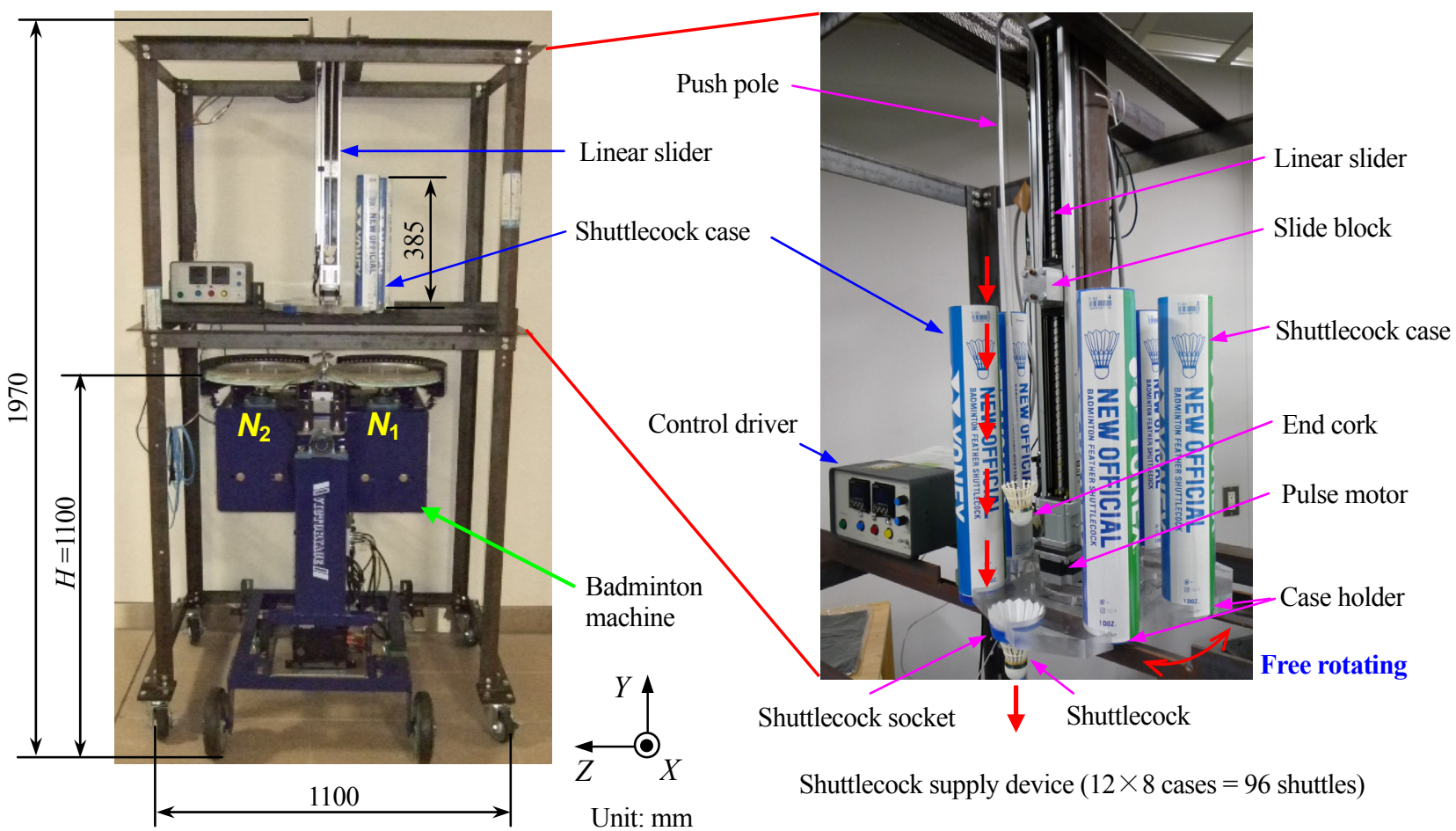

Fig. 3 The appearance and dimensions of the two roller-type badminton machine with the continuous launcher system are shown. The launcher system has a supply device for the shuttlecocks in which a maximum of eight dozen shuttlecocks can be inserted making for a total of $12 * 8=96$ shuttlecocks. This system pushes the shuttlecock at the top position inside the shuttlecock case by moving down the push pole (approximately $20 \mathrm{~mm}$ at one time), and the shuttlecocks at the bottom end of the case holder are supplied continuously to the badminton machine.

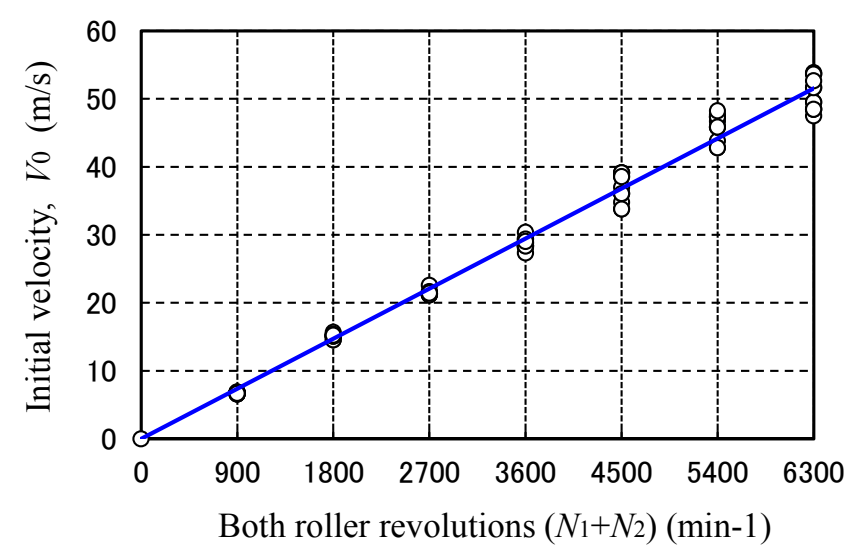

Fig. 4 The relationship between the sum of both roller revolutions $\left(N_{1}+N_{2}\right)$ and the initial velocity $V_{0}$ is shown. In the high-speed range of up to $30 \mathrm{~m} / \mathrm{s}$, the speed deviations become large. Between $\left(N_{1}+N_{2}\right)$ and $V_{0}$ exists a linear relation.

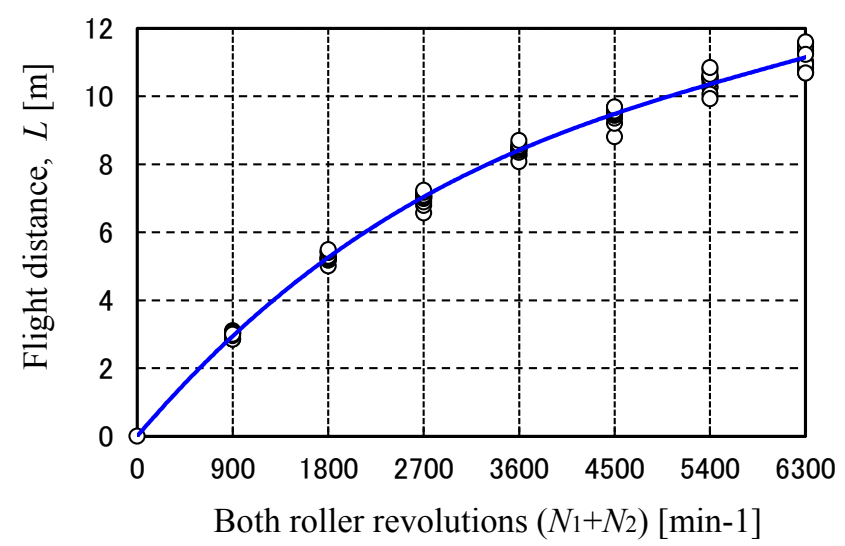

Fig. 5 The relationship between the sum of both roller revolutions $\left(N_{1}+N_{2}\right)$ and the flight distance $L$ is shown. Within a flight distance of up to $7 \mathrm{~m}$, the distance of the deviations becomes large. There is nonlinearity between $\left(N_{1}+N_{2}\right)$ and $V_{0}$. 
気温 $15^{\circ} \mathrm{C}$ 無風状態の屋内で実施した. 実験条件は，両ローラの回転数を等しく $\left(N_{1}=N_{2}\right)$, その和 $\left(N_{1}+N_{2}\right)$ を 900 6300 $\mathrm{min}^{-1}$ まで $900 \mathrm{~min}^{-1}$ ずつ増加させた 7 パターンである. 各パターンごとに 1 ダース (12 球) の水鳥シャ トルを連続に供給し, 合計 12 球 $\times 7=84$ 球の発射実験を行った.

両ローラ回転数の和 $\left(N_{1}+N_{2}\right)$ とシャトルの初速度 $V_{0}$ の関係を図 4 に示す. 図より, $30 \mathrm{~m} / \mathrm{s}$ 以上の高速域では 多少バラツキが大きくなるものの $V_{0}$ と $\left(N_{1}+N_{2}\right)$ にはほぼ比例関係がある.シャトルの飛翔後，落下した位置か ら飛距離 $L$ を計測した。図 5 に $\left(N_{1}+N_{2}\right)$ とシャトルの飛距離 $L$ の関係を示す. この場合, 両者の間には非線形 性が認められる. 飛距離は，発射時の初速度や仰俯角はもちろん，シャトルの空力係数やレイノルズ数等にも影 響されるからであると考えられる.

マシンからシャトルの発射方向を $X$, それと直角な方向（横方向）を $Z$ と，図 5 に示した各発射パターンに おけるシャトル落下位置を図 6 に示す。これより，ローラ回転数が速くなるほど飛距離は長くなり，落下位置の 範囲も広がっている. 横方向 ( $Z$ 方向) の落下位置に着目すると, 飛距離が $9 \mathrm{~m}$ を超えるとやや+Z方向に偏る傾 向があることがわかる：これは，シャトルの羽根の重なりによる長軸周りのスピン回転によるものと考えられ， 飛距離が長い場合, 飛行時間も長くなるため, その影響が顕著になるためだと予測される.

落下位置のバラツキを定量的に評価するため, 発射パターンごとの $X$ 方向と $Z$ 方向の標準偏差を算出した. そ の結果を図 7 に示す. $X$ 方向の標準偏差は, 両ローラ回転数が速くなるほど大きくなっていることがわかる. 一 方, $Z$ 方向の標準偏差は, $X$ 方向よりも值は小さく, その值はローラ回転数が 3600 min $^{-1}$ までは増加するものの,
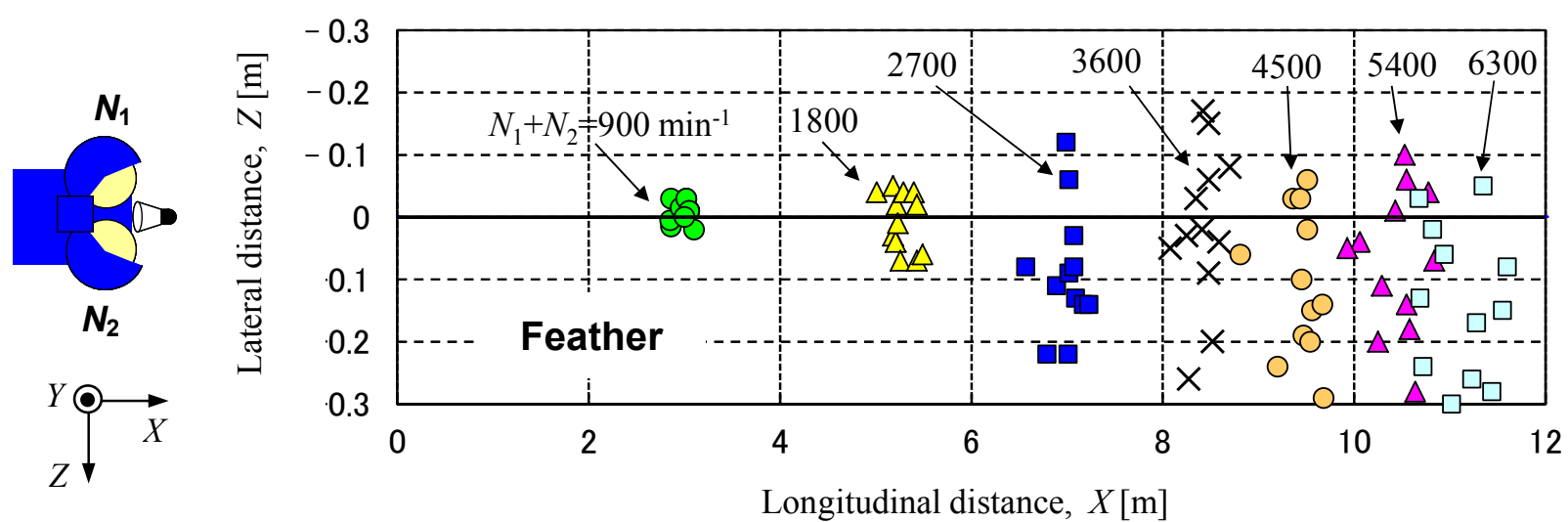

Fig. 6 The falling positions of the shuttlecocks under each roller revolution are shown. In the case where the roller revolution is higher, flight distance becomes longer, and the observation of the range of falling positions also spreads out.

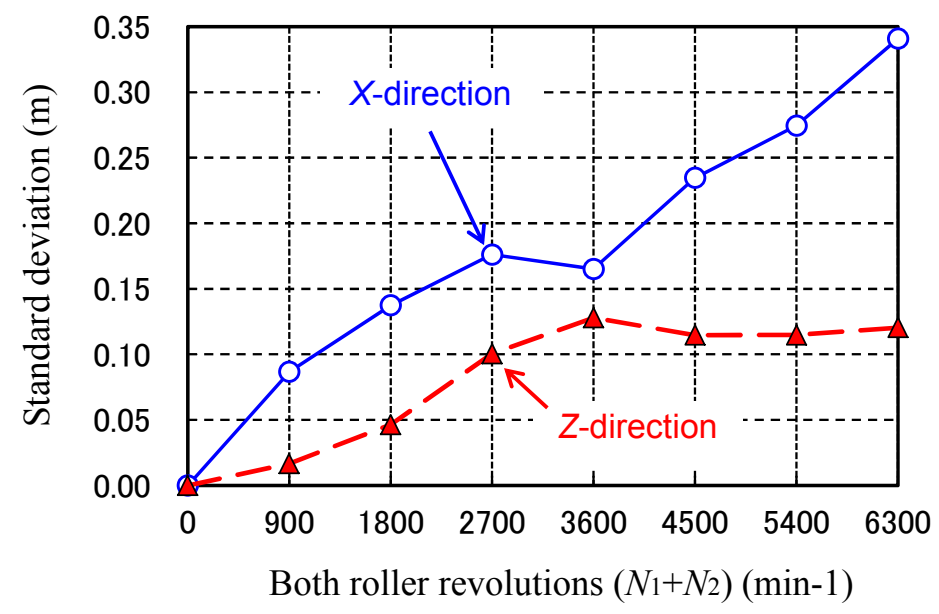

Fig. 7 This is the standard deviation of the $X$ - and $Z$-directions for falling positions under each roller revolution. The standard deviation for the $X$-direction grows into a bigger value as both roller revolutions reach higher speeds. When both roller revolutions are higher than $3600 \mathrm{~min}^{-1}$, the standard deviation of the Z-direction is an almost constant value (approximately $0.12 \mathrm{~m}$ ). 
$3600 \mathrm{~min}^{-1}$ 以上ではほぼ一定值（約 $0.12 \mathrm{~m}$ ）となっている. これより，水鳥シャトルの横方向のバラツキは，発射 方向よりも小さく最大 $0.13 \mathrm{~m}$ 前後であり直進性が伺える. また, シャトルの初速度による影響は小さく, 発射時 の偏角のバラツキが影響しているものと予測される. 他方, 発射方向のバラツキは, 発射時の初速度と仰俯角の 両者の変動が大きく影響し, 発射方向の標準偏差は, 初速度 $52 \mathrm{~m} / \mathrm{s}\left(N_{1}+N_{2}=6300 \mathrm{~min}^{-1}\right)$ のとき最大值 $($ 約 $0.34 \mathrm{~m})$ となった.

一般にバドミントン練習において要求される位置精度としては, 発射方向 $1.1 \mathrm{~m}$, 横方向 $1.0 \mathrm{~m}$ 以内である (酒 井他, 2011a). 開発したバドミントンの位置精度は, 発射, 横の両方向とも要求精度内に十分収まっており, 高い 位置精度を有している。

なお，本実験で 1 ダース（12 球）のシャトルを連射するのに要した時間は，約 18 秒であった．これは，シャ トル 1 球当り約 1.5 秒間隔で発射していることになる．トップレベル選手の練習においては，通常 1 球当り 1 秒 以下で実施されるため，連射装置のさらなる改良が必要である。しかし，本連射装置のシャトル押出用および発 射用の両ステッピングモータの回転速度にはまだ 3 倍以上の余裕があるため, シャトルの押出し，案内，把持装 置などを改良することによって，連射時間間隔の短縮化を行えるものと予測される.

\section{3. ニローラ式バドミントンマシンの改良と高速化}

開発したバドミントンマシンの発射性能の向上，特にシャトル発射速度のさらなる高速化（ $80 \mathrm{~m} / \mathrm{s}$ 以上）を実 現するため，シャトルの初期姿勢，シャトル把持具および発射用モータの検討を行った.

\section{$3 \cdot 1$ 発射時におけるシャトルの初期姿勢の検討}

本バドミントンマシンの発射時のシャトルは，垂直姿勢状態で発射ローラに挿入・案内後，発射される．その 様子は, 先行研究 (酒井他, 2011b) における画像分析から, 発射時のシャトルには, 並進方向の力だけでなく $Z$ 軸周りの回転モーメントも与えられ，これが発射速度に大きく影響するものと推測されている．そこで，回転モ 一メントを低減させるためシャトルを傾斜させて発射し， シャトルの初期姿勢が発射初速度に与える影響につい て検討した．発射時のシャトルの動的挙動を詳細に把握するため，有限要素解析を用いて検討を行った．解析に は，汎用の動的有限要素解析ソフトウェア ANSYS/ LS-DYNA Ver.12.0を使用した．なお，解析モデルの寸法や材 料定数，摩擦係数などの条件は，参考文献 (酒井他, 2011b) に詳述されているため，ここでは割愛する.

鉛直（ $Y$ 軸）方向とシャトルの長軸とのな寸角をシャトルの初期姿勢角 $\gamma$ とし， $\gamma=0^{\circ}$ および $45^{\circ}$ の二種類の解 析モデルを作製した． $\gamma=45^{\circ}$ のシャトルとローラ $\left(N_{1}\right)$ の解析モデルを図 8 に示す. なお，両モデルともシャト ルのコルクの最下点がローラ下端から $18 \mathrm{~mm}$ になるようにした. 発射条件は, 両発射ローラの回転数 $N_{1}=N_{2}=1800$ $\min ^{-1}$, シャトル挿入速度 $U_{0}=1 \mathrm{~m} / \mathrm{s}$ とした.

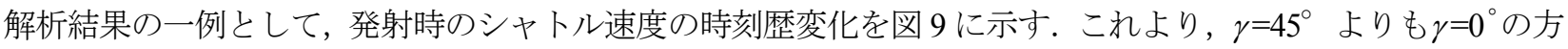

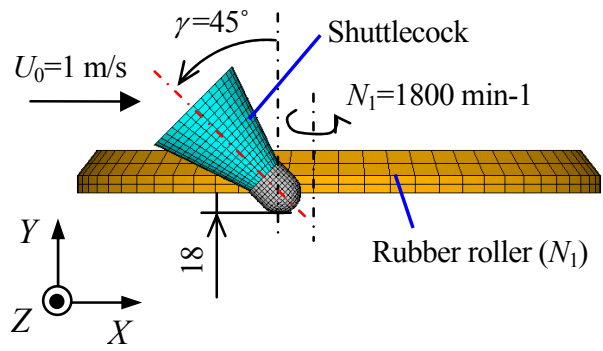

Fig. 8 Analysis model of the inclined shuttlecock and two rubber rollers is shown. $\gamma$ is the inclined angle of the shuttlecock. Both roller revolutions are $N_{1}=N_{2}=1800 \mathrm{~min}^{-1}$.

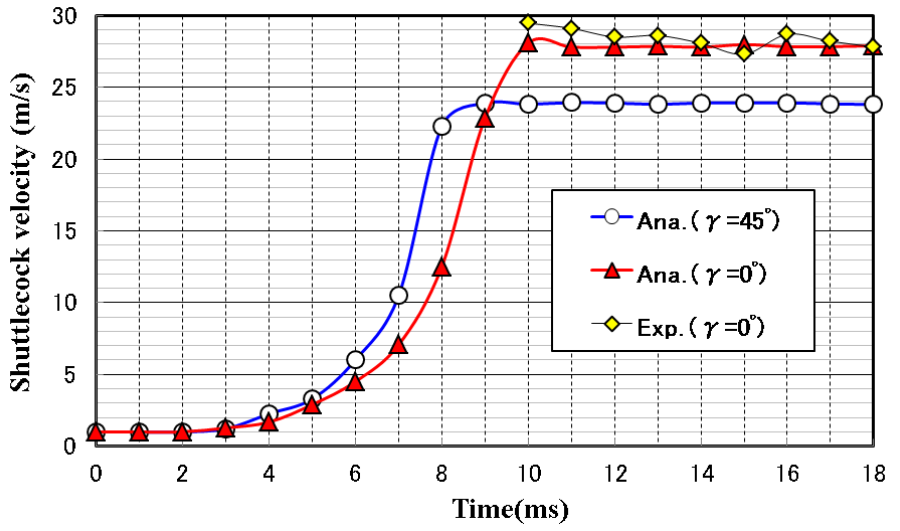

Fig. 9 The time-history of shuttlecock velocity for analysis (Ana.) and experiment (Exp.) during the launch are shown. In the case of $\gamma=0^{\circ}$, the shuttlecock speed is higher. 


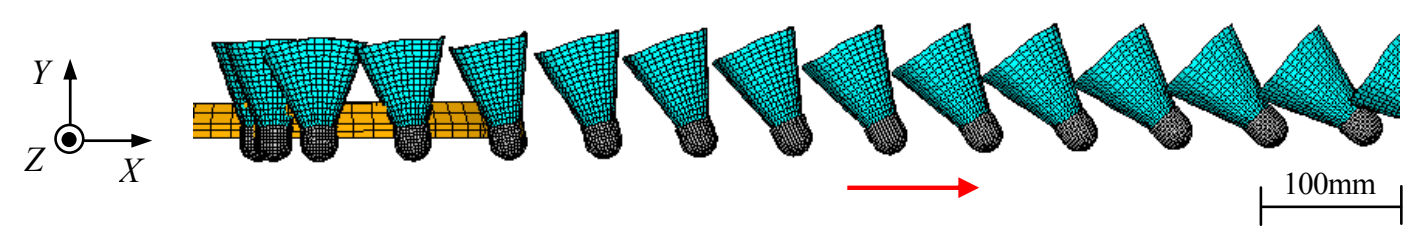

Fig. 10 After launch $\left(\gamma=0^{\circ}\right)$, the flight behavior of the shuttlecock obtained from a simulation is shown. This stroboscopic image is captured at every $2 \mathrm{~ms} /$ frame. Initial velocity of the shuttlecock is $28.1 \mathrm{~m} / \mathrm{s}$.

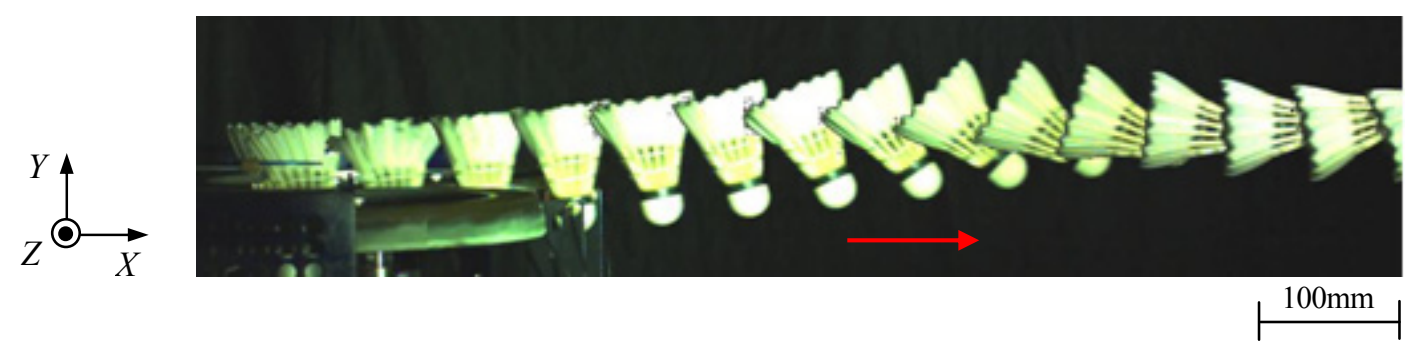

Fig. 11 After launch $\left(\gamma=0^{\circ}\right)$, the flight behavior of the shuttlecock captured using a high-speed video is shown. This stroboscopic image is captured at every $2 \mathrm{~ms} /$ frame. Initial velocity of the shuttlecock is $29.4 \mathrm{~m} / \mathrm{s}$.

が，発射速度が速いことがわかる．これは， $\gamma=45^{\circ}$ の場合，発射ローラがシャトルのコルクを十分に挟持するこ とができないためであると予測される．また，同じ発射条件における $\gamma=0^{\circ}$ の発射実験を本マシンで行い，側方か ら高速度ビデオカメラ（フォトロン製，FASTCAM SA5 model 1300K-C2）を用いて，シャトルの発射後の様子を 撮影速度 2000fps で撮影した。 その実験結果を図 9 に同時に示す。これより，解析では空気抵抗等が考慮されて いないため, 発射後の速度変化は完全には再現できてはいないものの初速度については, ほぼ同様の值となって いることがわかる.

$\gamma=0^{\circ}$ における発射後のシャトルの飛翔挙動の解析結果と実験結果を図 10,11 にそれぞれ示す. 両者を比較す ると, 発射直後のシャトルの飛翔姿勢はほぼ同様なのに対し, 空気抵抗力が支配的となる発射後 $10 \mathrm{~ms}$ 以降はそ の飛翔姿勢が異なっていることがわかる.

これより, シャトルの初期姿勢角 $\gamma$ を変更した発射解析を行った結果, 発射から $10 \mathrm{~ms}$ 後までの発射初速度等の 動的挙動は十分に再現できている. また， $\gamma=45^{\circ}$ の場合，発射初速度は約 $4 \mathrm{~m} / \mathrm{s}$ 低下するため, 発射時の初期姿勢 角としては，現在と同じ垂直姿勢 $\left(\gamma=0^{\circ}\right)$ がよいことがわかった.

\section{$3 \cdot 2$ シャトル把持具の検討}

次に, シャトル把持具についての検討を行った. 現在の把持具は図 2(c), (d) に示すように, シャトルは羽根保 持具，コルク把持具，底部保持具によって把持され，垂直（鉛直下向き）姿勢で保持されている. しかし，図 4 の発射初速度の結果からもわかるように, シャトルの初速度が約 $30 \mathrm{~m} / \mathrm{s}$ 以上になると, 明らかにバラツキが大き くなっていることがわかる．なお，ここでは示していないが．発射速度が速くなると仰俯角の值もバラツキが大 きくなる傾向があった.

これらの最大の原因は, 発射時のシャトルの姿勢が十分に保持されていないためであると考えられる. 発射時 シャトルは, ローラから発射方向 ( $X$ 方向) だけでなく, 高さ方向（ $Y$ 方向）にも挟持力を受ける. 現状の把持 具は，底部保持具によってシャトルは下方 $(-Y$ 方向 $)$ の移動は制限されているものの, 上方 $(+Y$ 方向 $)$ にはシ ヤトルの自重は軽いため, 容易に移動できる構造になっている. $30 \mathrm{~m} / \mathrm{s}$ を超える高速発射では, 高回転するロー ラの扇風作用により，シャトルがローラに近接するほど羽根部に浮力による上方向の力が発生し，ローラに対す る発射時のシャトル高さが常に一定とはならない，このような状態で発射をすると，シャトルのコルク部をロー ラが十分に挟持することができず結果として, シャトルの初速度や仰俯角のバラツキ発生の要因になっているこ とが十分に予測される．特に $50 \mathrm{~m} / \mathrm{s}$ を超える高速発射では，仰角が大きい飛翔軌道のものやシャトルがローラに ほとんど挟持されずローラに弾かれたような現象，いわゆる上方にすっぽ抜けたような飛翔をすることもまれに 生じることがあった.

そこで，図 12 に示すように新たなシャトル把持具を設計，製作をした．新把持具では，シャトルの羽根 16 枚 
を結束，固定している上下の紐の間の台形隙間 : A 部（高さ約 $10 \mathrm{~mm} ，$ 図 1 参照）を側面から貫通（串刺）する 幅 $8 \mathrm{~mm}$ 板厚 $1 \mathrm{~mm}$ のナイフ状の案内ガイドを設けた。 このナイフ形ガイドによって, シャトルのローラへの挿入 および発射時の上方向（+Y方向）への移動を拘束した. また, 羽根保持具, コルク把持具, 底部保持具につい ては，シャトル姿勢を維持しつつ発射方向（X方向）へスムーズな移動を実現させるため，これらの形状を図の ように変更し, ローラへの挿入・発射時におけるシャトル高さと初期姿勢の安定性を旧把持具よりも向上させた.

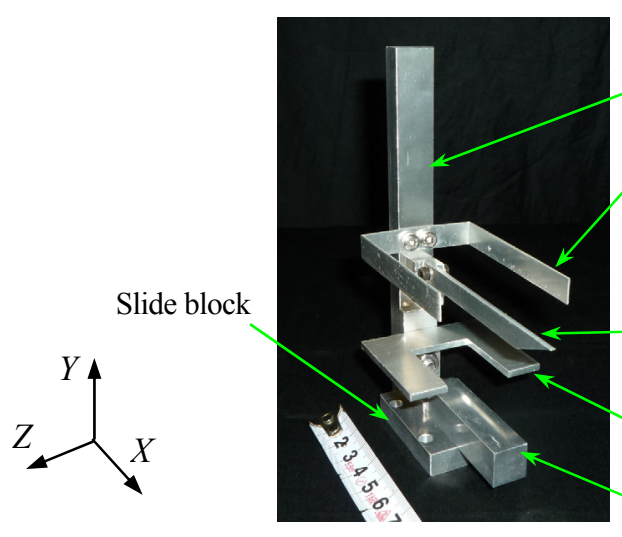

(a) Without shuttlecock

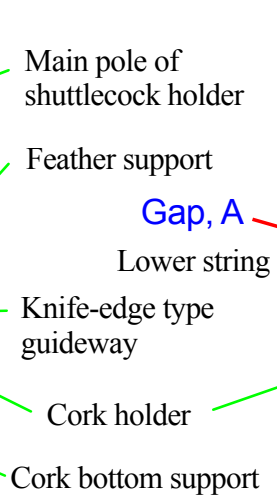

Cork bottom support

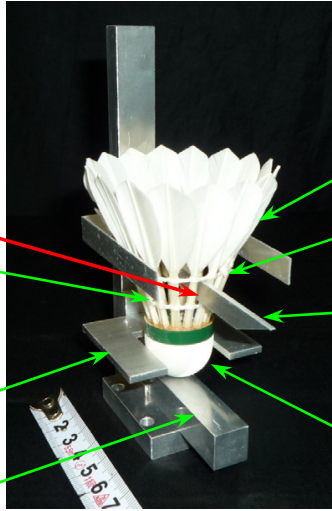

(b) With shuttlecock
Feather

Upper string

Knife-edge type guideway

Cork

Fig. 12 Appearances of the advanced holder device for the shuttlecock are shown. The advanced holder device is installed with a cork holder, cork bottom support, feather support and knife-edge type guideway, and the shuttlecock is discharged smoothly in $X$-direction while keeping its posture. Using the advanced holder device, the badminton machine can launch shuttlecocks at higher speeds.

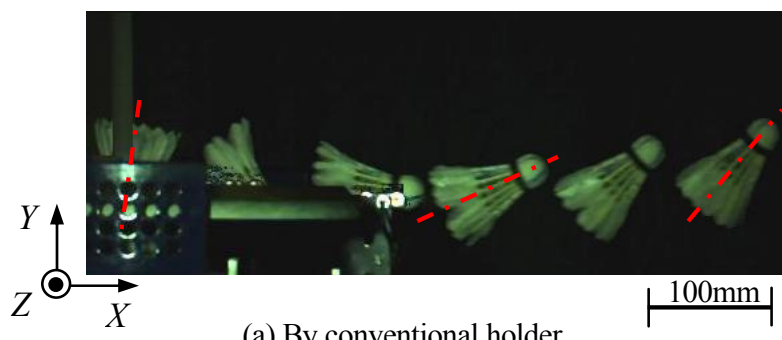

(a) By conventional holder

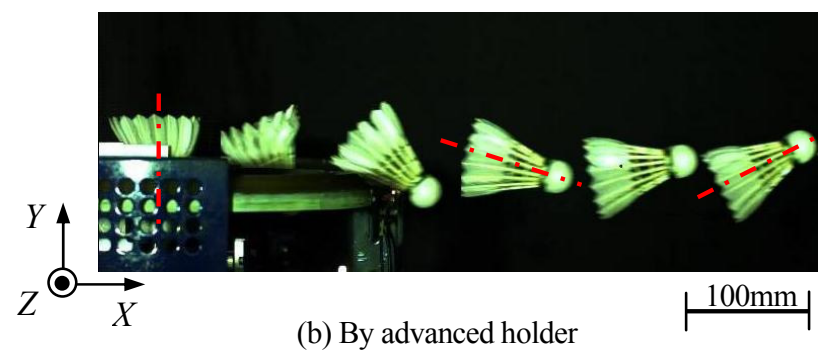

(b) By advanced holder

Fig. 13 Stroboscopic images at every $2 \mathrm{~ms}$ of flight behavior after shuttlecock launch by conventional and advanced holder devices are shown in Figs. (a) and (b), respectively. Looking at both images, the flight postures of the shuttlecock differ clearly. In the advanced holder device, the rotation moment of the circumference in the $Z$-axis after launch is reduced.

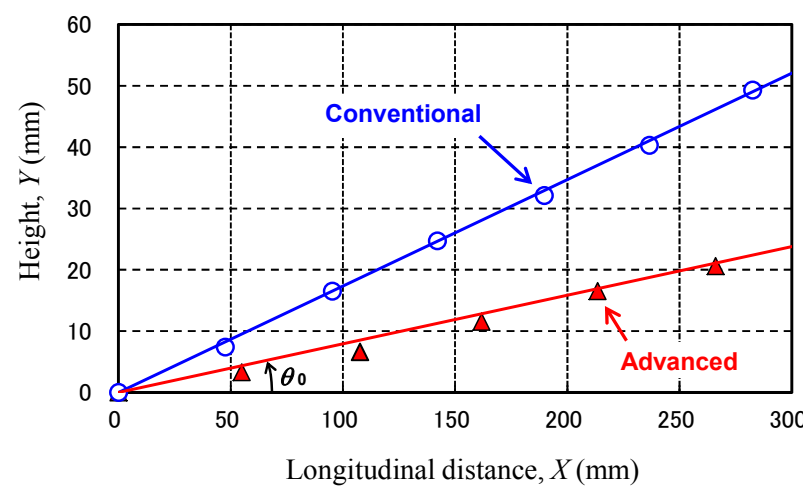

Fig. 14 The flight trajectories at the nose end of the shuttlecock at every $1 \mathrm{~ms}$ by both holder devices are shown. The launcher angle $\theta_{0}$ of the advanced holder is small compared to the conventional one.
Table 1 The mean (Mean) and standard deviation (SD) of the initial velocity $V_{0}$ and launcher angle $\theta_{0}$ by both holder types are shown, respectively. The mean values of $V_{0}$ and $\theta_{0}$ of the advanced holder are quicker $(5.0 \mathrm{~m} / \mathrm{s})$ and smaller $(4.0$ degrees) than for the conventional one.

\begin{tabular}{c|c|c|c|c|}
\hline \hline \multirow{2}{*}{ Holder type } & \multicolumn{2}{|c|}{ Initial velocity, $V_{0}(\mathrm{~m} / \mathrm{s})$} & \multicolumn{2}{c}{ Lancher angle, $\theta_{0}$ (degree) } \\
\cline { 2 - 5 } & Mean & $\mathrm{SD}$ & Mean & $\mathrm{SD}$ \\
\hline $\begin{array}{c}\text { Conventional holder } \\
\text { (Without guideway) }\end{array}$ & 49.3 & 2.8 & 8.6 & 2.8 \\
\hline $\begin{array}{c}\text { Advanced holder } \\
\text { (With guideway) }\end{array}$ & 54.3 & 1.1 & 4.6 & 1.7 \\
\hline
\end{tabular}




\section{$3 \cdot 3$ 新旧シャトル把持具の発射性能の比較}

両ローラ回転数が $N_{1}=N_{2}=3000 \mathrm{~min}^{-1}$ の条件下で新・旧のシャトル把持具を用いて, それぞれ各 10 球の発射実験 を行った. シャトル発射の様子を側方から高速度ビデオカメラを用いて，撮影速度 $1000 \mathrm{fps}$ で撮影した.

実験結果の一例として，両把持具における発射時の $2 \mathrm{~ms}$ ごとのストロボ画像を図 13(a), (b) にそれぞれ示す. シャトルの発射直前の両画像を比較すると，旧把持具ではシャトルがやや前屈姿勢であるが，新把持具ではほぼ 同じ垂直姿勢が維持されている．また，3〜6コマ目のシャトルの飛翔姿勢に着目寸ると，明らかに飛翔姿勢が異 なっており，新把持具では発射後の $Z$ 軸周りの回転モーメントが抑制されていることがわかる．これは，ナイフ 形ガイドの効果によるものと考えられる.

次に, 撮影したストロボ画像（図 13）からシャトルのコルク先端の飛翔軌道を $1 \mathrm{~ms}$ ごとに計測した. その結果 を図 14 に示寸.これより, 発射直後の飛翔軌道はシャトルの回転モーメントの影響があるため, 多少非線形性が 認められるものの，その後の軌道は把持具の種類に関わらず，ほぼ線形である，一方，把持具の種類によって飛 翔軌道の仰角は異なり，新把持具は旧把持具に比べて仰角が小さい軌道を描く。これは，ナイフ形ガイドによる シャトルの浮き上がり防止効果と考えられ，ナイフ形ガイドでシャトル側面を串刺すことによって，発射時のシ ヤトル高さと姿勢の維持に貢献しているものと予測される.

両把持具で各 10 球ずつ発射したときの初速度 $V_{0}$ および仰角 $\theta_{0}$ の平均值（Mean），標準偏差（SD）をそれぞれ 表 1 に示寸. 表より, 新把持具は旧把持具に比較して, 初速度は約 $5.0 \mathrm{~m} / \mathrm{s}$ 速く, 仰角は約 $4.0^{\circ}$ 小さい. 他方, 両 者の標準偏差は，いずれも新把持具では旧把持具よりも小さい值になっている.この理由は，新把持具を用いる とシャトルの挿入高さと姿勢のバラツキが抑制されるため, 発射ローラのコルク挟持状態が安定したことが大き く影響しているものと推察される.

以上より，改良した新把持具は，旧把持具と比較して約 $9 \%$ 発射初速度が上昇し，発射速度，仰角ともにバラ ツキが低下し，安定して発射することが可能となった。

\section{$3 \cdot 4$ 発射用モ一タの改良}

バドミントンマシンのさらなる高速化を実現するため, 発射用モータを変更する改良を実施した. 図 2(a) に示

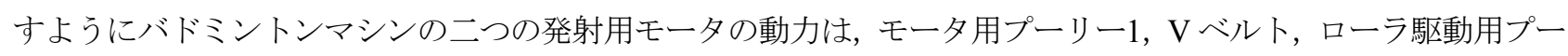
リー2, ローラシャフトを介して，発射ローラにそれぞれ伝達される. 現状の発射用モータの性能・仕様は，M 社製, 三相 $200 \mathrm{~V}$, 極数 4 , 出力 $0.2 \mathrm{~kW}$, 定格回転数 $1690 \mathrm{~min}^{-1}$ である. 両プーリー 1,2 の直径比は 1.67 であり, モータ側に大径プーリー1 を用いて 1.67 倍の増速を行っている. インバータ装置の入力周波数を $70 \mathrm{~Hz}$ に設定し た場合, ローラの回転数は $3150 \mathrm{~min}^{-1}$ になり, ほぼ最高回転数に達する. このとき, 発射ローラ外周の周速は, ローラ外径が $\phi 315 \mathrm{~mm}$ なので $52.0 \mathrm{~m} / \mathrm{s}$ となる. インバータへの入力周波数を高くすることによって, さらに高速 回転が可能ではあるものの，長時間の連続運転ではモータ焼損の恐れもあり，実用的には，この值が現マシンの シャトル発射初速度の限界と予測される。

そこで, 本研究目標である発射初速度 $80 \mathrm{~m} / \mathrm{s}$ を達成するため, 高回転, 高出力のモータに変更することにした. 本マシンの発射装置の構造や寸法上の制約を考慮し, 次の性能・仕様のモータを選定した.

[新モー夕の性能・仕様 : $M$ 社製, 三相 $200 \mathrm{~V}$, 極数 2 , 出力 $0.4 \mathrm{~kW}$, 定格回転数 $3380 \mathrm{~min}^{-1}$ ]

このモータの選定理由としては, 両プーリーによる増速比を 1.67 , インバータ周波数を定格周波数 $(60 \mathrm{~Hz})$ と すると，ローラ回転数は $5645 \mathrm{~min}^{-1}$ になり，このときローラの外周速は計算上， $93.1 \mathrm{~m} / \mathrm{s}(335 \mathrm{~km} / \mathrm{h})$ に達するか らである.ローラ外周速がシャトルの発射初速度とほぼ等しいと仮定した場合, 全日本トップレベル選手のスマ ッシュ速度と同等，またはそれ以上の速度で発射可能となる。

上記の新モータ 2 台を本マシンに搭載した. なお, 断続運転や頻繁な加減速なども考慮し, インバータ装置は, モータ出力よりも大きい容量 $0.75 \mathrm{~kW}$ のものを使用した. また, 減速時における制動能力を向上させるため, 新 たにブレーキ抵抗器を設けた.

\section{$3 \cdot 5$ 改良型ニローラ式バドミントンマシンの発射性能}

前節までの改良を施した改良型二ローラ式バドミントンマシンを用いて, 発射実験を行った。実験条件は，両 ローラの回転数を等しく $\left(N_{1}=N_{2}\right)$ し，その和 $\left(N_{1}+N_{2}\right)$ を $10000 \mathrm{~min}^{-1}$ まで $2000 \mathrm{~min}^{-1}$ ずつ増加させた 5 パターン 
で，各パターンごとに 10 球 (合計 : 50 球) の発射実験を行った. また，発射時のシャトルの挙動を側方から高 速度ビデオカメラを用いて，撮影速度 1000fps で撮影した。

実験結果の一例として，シャトルの初速度 $V_{0}$ と両ローラ回転数の和 $\left(N_{1}+N_{2}\right)$ の関係を図 15 に示す. 図より， $V_{0}$ と $\left(N_{1}+N_{2}\right)$ はほぼ比例関係にあること, $60 \mathrm{~m} / \mathrm{s}$ 以下の初速度ではバラツキが小さいものの, それ以上の高速域 ではバラツキがやや大きくなっていることがわかる. $N_{1}+N_{2}=10000 \mathrm{~min}^{-1}$ のとき最高初速度となり，その平均值は $81.8 \mathrm{~m} / \mathrm{s}$ であった．この值を時速に換算すると約 $295 \mathrm{~km} / \mathrm{h}$ になる．僅かに $300 \mathrm{~km} / \mathrm{h}$ には達してはいないものの， 全日本のトップレベル選手のスマッシュ速度とほぼ同等の発射速度が得られている.

最高初速度におけるシャトル発射時の挙動の代表例として, $1 \mathrm{~ms}$ ごとのストロボ画像を図 16 に示す.これより， 低・中速発射時における図 11 および $13(\mathrm{~b})$ の両画像と図 16 を比較すると，高速発射 $\left(V_{0}=82.0 \mathrm{~m} / \mathrm{s}\right)$ 時において は，発射中および直後はシャトルに大きな並進加速度が加わるため，シャトルの羽根がやや曲がっているものの $80 \mathrm{~m} / \mathrm{s}$ を超える高速発射にも関わらず, 羽根部の破損は生じなかった. 高速発射時における初速度のバラツキは, シャトルのコルク部の挟持状態が低・中速発射時よりも大きく影響するものと予測されるが，羽根のたわみ変形 も多少影響するのではないかと考えられる.

また，両者の飛翔軌跡を比較すると，低速発射の場合は仰角 $\theta_{0}$ が大きくやや上方に飛翔する軌跡となるが，高 速発射時ではほぼ水平 $\left(\theta_{0} \fallingdotseq 0\right)$ に近い軌跡を描いている. これは，発射速度が $60 \mathrm{~m} / \mathrm{s}$ を超える高速域になると並 進方向の力が支配的となり，相対的に $Z$ 軸周りの回転モーメントが小さくなることが推察される. 一方，両者と も発射後の飛翔姿勢にはそれほど大きな違いはなく，低・中速発射時と同様，高速発射時においても非常にスム 一ズに発射できていることがわかる。

図 15 に示した各発射パターンにおける改良型マシンのシャトル落下位置を図 17 に示す. 両ローラ回転数が速 くなるほど落下位置の範囲は広がっていくことがわかる。一方，飛距離は，両ローラ回転数が $8000 \mathrm{~min}^{-1}$ までは 回転数が速くなるほど長くなるものの，10000 $\mathrm{min}^{-1}$ の場合は飛距離が短くなっている. これは，低・中速発射時 と比べて高速発射時では，発射仰角が小さくなるために飛距離が短くなったものと考えられる.

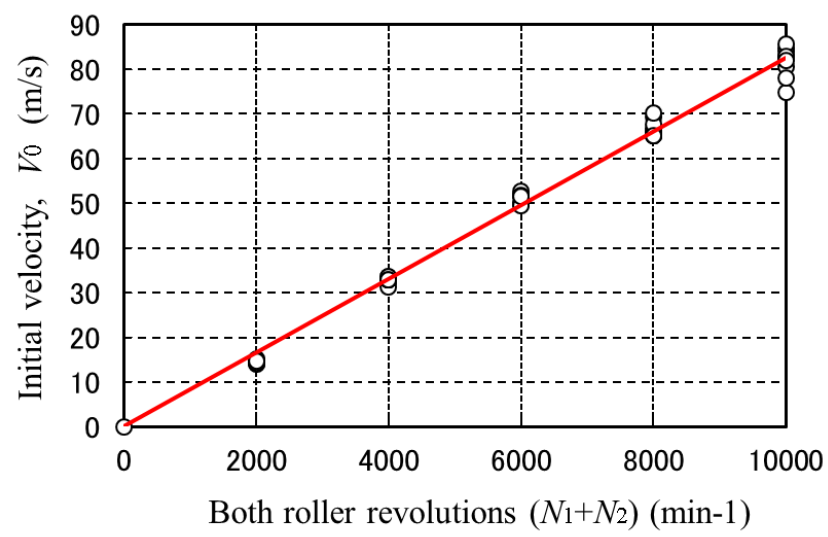

Fig. 15 The relationship between the sum of both roller revolutions $\left(N_{1}+N_{2}\right)$ and the initial velocity $V_{0}$ by the advanced two roller-type badminton machine is shown. In the high-speed range of up to $60 \mathrm{~m} / \mathrm{s}$, speed deviations become large. Between $\left(N_{1}+N_{2}\right)$ and $V_{0}$ is almost linear relationship. The highest initial velocity of the advanced machine reached approximately $81.8 \mathrm{~m} / \mathrm{s}(295 \mathrm{~km} / \mathrm{h})$. Therefore, this machine has a high shot performance.

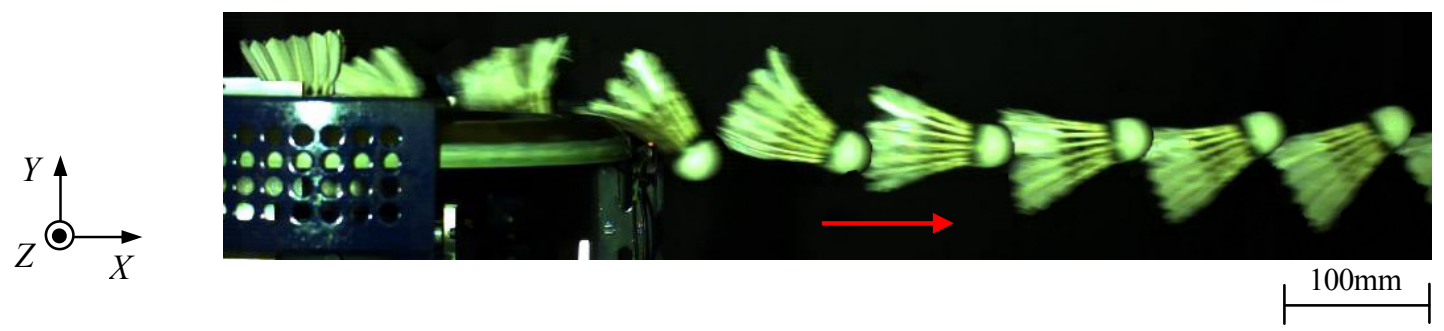

Fig. 16 For example, the flight behavior of the shuttlecock under the highest initial velocity is shown. This stroboscopic image is captured at every $1 \mathrm{~ms} /$ frame using high-speed video. Initial velocity of the shuttlecock is $82.0 \mathrm{~m} / \mathrm{s}$. 

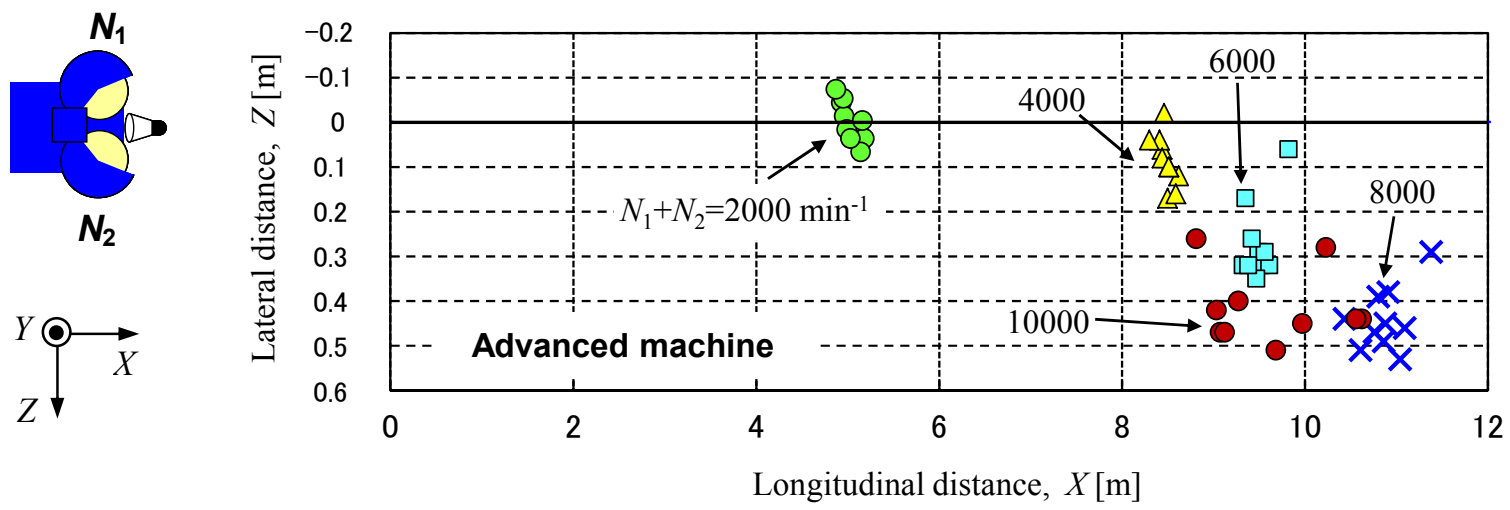

Fig. 17 The falling positions of the shuttlecocks under each roller revolution by the advanced machine are shown. In the case of the roller revolution to $8000 \mathrm{~min}^{-1}$ is higher, the flight distance and the range of falling positions become longer. The flight distance decreases adversely when the roller revolution is higher than $8000 \mathrm{~min}^{-1}$.

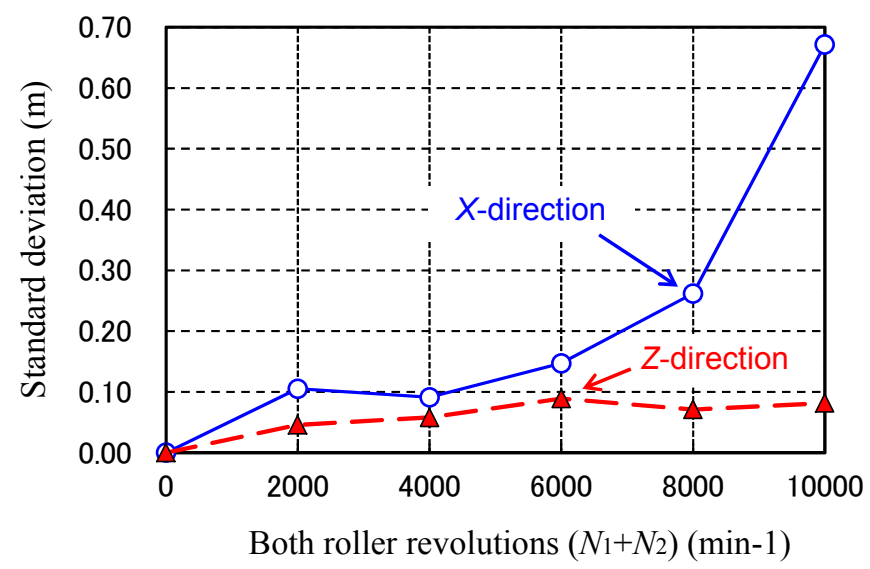

Fig. 18 This is the standard deviation of the $X$ - and $Z$-directions for falling positions by the advanced machine. The standard deviation for the $X$-direction grows into a bigger value as both roller revolutions reach higher speeds. When both roller revolutions are higher than $6000 \mathrm{~min}^{-1}$, the standard deviation of the Z-direction is an almost constant value (approximately $0.09 \mathrm{~m}$ ).

落下位置（図 17）の $X$ 方向と $Z$ 方向の標準偏差を図 18 に示寸. $X$ 方向の標準偏差は, 両ローラ回転数が速く なるほど大きくなり， $8000 \mathrm{~min}^{-1}$ を境にその值は急激に増加する。これは，図 15 に示したように高速域では初速 度のバラツキが大きいことが起因しているものと推察される.一方， $Z$ 方向の標準偏差は, 図 7 と同様, $X$ 方向 よりも值は小さく, その值はローラ回転数が $6000 \mathrm{~min}^{-1}$ までは増加するものの, $6000 \mathrm{~min}^{-1}$ 以上ではほぼ一定值に なっている. 横方向の標準偏差は, 発射方向よりも小さく最大 $0.09 \mathrm{~m}$ 前後であった. これは, 改良型マシンに用 いた新把持具は，発射時の偏角のバラツキを抑制する効果もあるものと考えられる. 両ローラ回転数（初速度） がほぼ等しい条件で旧型マシンの位置精度（図 7）と比較すると, 改良型マシンは, 発射および横方向の両者と もに標準偏差は小さくなっており，位置精度が向上していることがわかる.

以上，新把持具，高速モータを採用した改良型二ローラ式バドミントンマシンは，シャトル発射時に羽根を損 傷することなく初速度が $80 \mathrm{~m} / \mathrm{s}$ を超え，既存のバドミントンマシンを遥かに凌ぐ高い発射性能を有している．本 マシンは，大学生はもちろん全日本のトップレベル選手が行うスマッシュやクリアのリターン練習など幅広く活 用できる実用的練習マシンとして十分な性能があると言える.

最後に，本論文では議論をしていないが，図２に示すように開発したバドミントンマシンは，ロール回転用八

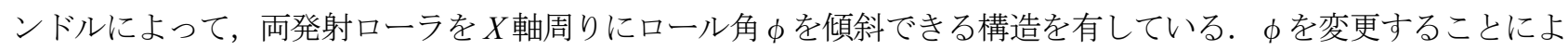
り，実際のストローク動作の一つ，ラケットを $X$ 軸周りに傾けて打撃したときのシャトル姿勢と同じ傾斜したシ ヤトル姿勢で発射することが可能である.このとき，旧把持具ではシャトル姿勢の維持は困難であるが，ナイフ 形ガイド付きの新把持具では， $\phi$ を傾斜させてもシャトルの位置と姿勢が変動することなく安定して挿入，発射 ができるものと考えられる．なお， $\phi$ を変化させた場合のシャトルの飛翔軌道は，三次元的に変化するものと推 
測されるがこれについては今後検討をしたい.

\section{4. 結 言}

本研究では, 開発した二ローラ式バドミントンマシンの発射性能の向上を行った. 連射性能の向上については, シャトルを自動供給し，連続的に発射できるシャトル連射装置を製作した，発射速度の高速化については，シャ トルの把持姿勢の検討, 把持具の改良, 高速モータへの変更等を実施し, その結果, 旧バドミントンマシンと比 較して 1.5 倍以上の高速化を実現した. 得られた結言は次の通りである.

(1) 開発したシャトル連射装置は，1 球当り約 1.5 秒間隔で 12 球（最大 96 球）の連続発射が可能である. また, 二ローラ式バドミントンマシンと連動させた連射実験の結果, 最大飛距離 $11 \mathrm{~m}$, 発射方向および横方向の落 下位置誤差は，それぞれ $0.34 \mathrm{~m} ， 0.12 \mathrm{~m}$ であり，高い連射性能を有している。

（2）改良型二ローラ式バドミントンマシンの最高初速度は $80 \mathrm{~m} / \mathrm{s}$ を超え，全日本トップレベル選手を対象とする 実用的練習マシンとして使用できる.

\section{謝 辞}

本研究は，JSPS 科研費 No.24560255 の助成を受けたものである．ここに謝意を表する．

\section{文献}

Alam, F., Chowdhury, H., Theppadungporn, C., Subic, A. and Khan, M. K., Aerodynamic properties of badminton shuttlecock, International Journal of Mechanical and Materials Engineering, Vol. 4, No. 3 (2009), pp.266-272.

蘆田浩規, 小塚晃弘, 鳴尾丈司, 佐藤文宣, バドミントンラケットとシャトルコックのインパクト挙動, 日本機械 学会 ジョイント・シンポジウム 1998, No.98-31 (1998), pp.148-152.

蘭 和真, 競技バドミントンの運動強度: 時間設定方式のゲーム練習と公式試合の運動強度の比較, 東海女子大学 紀要, Vol.20 (2000), pp.179-189.

Cooke, A.J., Shuttlecock aerodynamics, Sports Engineering, Vol.2 (1999), pp.85-96.

Cooke, A.J., Computer simulation of shuttlecock trajectories, Sports Engineering, Vol.5, No.2 (2002), pp.93-105.

Hubbard, M., and Cooke, A.J., Spin dynamics of the badminton shuttlecock, 6th international symposium on computer simulation in biomechanics (1997), pp.42-43.

石崎繁利, 田中裕一, 鍋野幸大, 笠井正三郎, 英 崇夫, バドミントン練習機の開発, 工学・工業教育研究講演会講 演論文集 平成 22 年度, No.9-107 (2010), pp.188-189.

板倉嘉哉, 古村文音, 身近な遊具等の工学的解析(その 2:バドミントン用シャトルコックのダイナミクス), 千葉大 学教育学部研究紀要, Vol.61 (2013), pp.463-471.

Marshall, R. N. and Elliott, B. C., Long-axis rotation: The missing link in proximal-to-distal segmental sequencing, Journal of Sports Sciences, Vol.18, No.4 (2000), pp.247-254.

酒井 忍, 野辺亮太, 水口さゆり，村口さよ，二ローラ式バドミントンマシンの開発，日本機械学会論文集 C 編, Vol.77, No.781 (2011a), pp.3415-3426.

酒井 忍, 北山 哲士, 野辺亮太, 水口さゆり, ローラ式バドミントンマシンの開発と性能向上, 日本機械学会論文 集 C 編, Vol.77, No.783 (2011b), pp.3978-3989.

Kitta, S., Hasegawa, H., Murakami, M. and Obayashi, S., Aerodynamic properties of a shuttlecock with spin at high Reynolds number, 5th Asia-Pacific Congress on Sports Technology (APCST), Vol.13 (2011), pp.271-277.

湯 海鵬, 阿部一佳, 加藤幸司, バドミントンのスマッシュ動作の 3 次元動作解析: 前腕と手関節の動きを中心に, 体育学研究, Vol.38, No.4 (1993), pp.291-298.

Tan, J.C.C., Foong, S.K., Veluri, S. and Sachdeva, S., Testing of badminton shuttles with a prototype launcher, The impact of Technology on Sport II (2008), pp. 443-448.

綿貫忠晴, 鈴木宏二郎, バドミントン用シャトルコックの基礎的空力特性, 第 38 回流体力学講演会講演論文集 (日本航空宇宙学会), 1B7 (2006), pp.89-92.

Wonisch, M., Hofmann, P., Schwaberger, G., Duvillard, S.P. and Klein, W., Validation of a field test for the non-invasive 
determination of badminton specific aerobic performance, British Journal Sports Medicine, Vol.37, No.2 (2003), pp.115-118.

Yousif, B.F. and Yeh, K.S., Badminton training machine with impact mechanism, Journal of Engineering Science and Technology, Vol.6, No.1 (2011), pp.61-68.

\section{References}

Alam, F., Chowdhury, H., Theppadungporn, C., Subic, A. and Khan, M. K., Aerodynamic properties of badminton shuttlecock, International Journal of Mechanical and Materials Engineering, Vol. 4, No. 3 (2009), pp.266-272.

Ashida, H., Kozuka, A., Naruo, T. and Sato, F., Behavior of badminton racket and shuttlecock at impact, Proceedings of Joint Symposium 1998, No.98-31 (1998), pp.148-152 (in Japanese).

Araragi, K., Thephysiological studies on physical demands in competitive badminton: An investigation from the view points of the work intensity of practice games and official games of elite female, Departmental Bulletin Paper, Research Bulletin, Tokai Women's Junior College, Vol.20 (2000), pp.179-189 (in Japanese).

Cooke, A.J., Shuttlecock aerodynamics, Sports Engineering, Vol.2 (1999), pp.85-96.

Cooke, A.J., Computer simulation of shuttlecock trajectories, Sports Engineering, Vol.5, No.2 (2002), pp.93-105.

Hubbard, M., and Cooke, A.J., Spin dynamics of the badminton shuttlecock, 6th international symposium on computer simulation in biomechanics (1997), pp.42-43.

Ishizaki, S., Tanaka, Y., Nabeno, T., Kasai, S. and Hanabusa, T., Development of practice machine for badminton, Japanese Society for Engineering Education (JSEE) Annual Conference 2010 , No.9-107 (2010), pp.188-189 (in Japanese).

Itakura, Y. and Komura, A., Engineering analysis of a familiar plaything (2nd report: Dynamics of badminton shuttlecock), Research Bulletin of the Faculty of Education, Chiba University, Vol.61 (2013), pp.463-471 (in Japanese).

Marshall, R. N. and Elliott, B. C., Long-axis rotation: The missing link in proximal-to-distal segmental sequencing, Journal of Sports Sciences, Vol.18, No.4 (2000), pp.247-254.

Sakai, S., Nobe, R., Mizuguchi, S. and Muraguchi, S., Development of launcher machine with two rollers for badminton, Transactions of the Japan Society of Mechanical Engineers, Series C, Vol.77, No.781 (2011a), pp.3415-3426 (in Japanese).

Sakai, S., Kitayama, S., Nobe, R. and Mizuguchi, S., Development and improving performance of roller type badminton machine, Transactions of the Japan Society of Mechanical Engineers, Series C, Vol.77, No.783 (2011b), pp.3978-3989 (in Japanese).

Kitta, S., Hasegawa, H., Murakami, M. and Obayashi, S., Aerodynamic properties of a shuttlecock with spin at high Reynolds number, 5th Asia-Pacific Congress on Sports Technology (APCST), Vol.13 (2011), pp.271-277.

Tang, H.P., Abe, K. and Katoh, K., Three-dimensional cinematographical analysis of the badminton forehand smash: movement of the forearm and hand, Japan Society of Physical Education, Health and Sport Sciences, Vol.38, No.4 (1993), pp.291-298 (in Japanese).

Tan, J.C.C., Foong, S.K., Veluri, S. and Sachdeva, S., Testing of badminton shuttles with a prototype launcher, The impact of Technology on Sport II (2008), pp. 443-448.

Watanuki, T. and Suzuki, K., The fundamental aerodynamic characteristics of the badminton shuttlecocks, 38th Fluid Dynamics Conference, (The Japan Society for Aeronautical and Space Sciences), 1 B7 (2006), pp.89-92 (in Japanese).

Wonisch, M., Hofmann, P., Schwaberger, G., Duvillard, S.P. and Klein, W., Validation of a field test for the non-invasive determination of badminton specific aerobic performance, British Journal Sports Medicine, Vol.37, No.2 (2003), pp.115-118.

Yousif, B.F. and Yeh, K.S., Badminton training machine with impact mechanism, Journal of Engineering Science and Technology, Vol.6, No.1 (2011), pp.61-68. 